\title{
New Plants for Florida: Varieties Produced by the Florida Agricultural Experiment Station--Table of Contents ${ }^{1}$
}

Richard L. Jones, Mary Duryea, and Berry J. Treat, Editors ${ }^{2}$

Tropical Pumpkin

Peanut

\section{Table of Contents}

Introduction/Message from the Dean

Blueberry

Strawberry

Grape

Stone Fruit

Tropical Fruit

Citrus

Watermelon

Tomato

Sweet Corn

\section{Grain}

Sugarcane

Forage

Turfgrass

Tropical Foliage

Lisianthus

Pine

Molecular Genetics for Enhanced Plant Breeding

Conclusion/Other Varieties

Dedication/Acknowledgment

1. This document is part of Circular 1440, a publication of the Florida Agricultural Experiment Station, the Agronomy Department and IFAS Communication Services, Florida Cooperative Extension Service, Institute of Food and Agricultural Sciences, University of Florida. Publication date August 2003. Originally published as a booklet by IFAS Communication Services June 2003. Visit the EDIS Web Site at http://edis.ifas.ufl.edu.

2. Richard L. Jones, Dean for Research, Mary L. Duryea, Assistant Dean for Research, and Berry J. Treat, Assistant Director for Research Programs, Florida Agricultural Experiment Station, Institute of Food and Agricultural Sciences, University of Florida, Gainesville, FL 32611.

Florida Agricultural Experiment Station, Institute of Food and Agricultural Sciences, University of Florida, Richard L. Jones, Dean for Research, publishes this information to further programs and related activities, available to all persons regardless of race, color, age, sex, disability or national origin. Information about alternate formats is available from IFAS Communication Services, University of Florida, PO Box 110810, Gainesville, FL 32611-0810.

The Institute of Food and Agricultural Sciences is an equal opportunity/affirmative action employer authorized to provide research, educational information and other services only to individuals and institutions that function without regard to race, color, sex, age, handicap, or national origin. For information on obtaining other extension publications, contact your county Cooperative Extension Service office. Florida Cooperative Extension Service/Institute of Food and Agricultural Sciences/University of Florida/Christine Taylor Waddill, Dean. 


\section{Contributors}

Fredy Altpeter, Ron Barnett, Ann Blount, Carl Campbell, Bill Castle, Craig Chandler, Dave Clark, Jonathan Crane, Mary Duryea, Rob Gilbert, Fred Gmitter, Jr., Dan Gorbet, Dennis Gray, Jude Grosser, Curt Hannah, Brent Harbaugh, Jake Henny, Richard Jones, Harry Klee, Bob Knight Jr., Kathy Krawchuk, Paul Lyrene, Jimmy Miller, Don Maynard, Gloria Moore, Russell Nagata, Joseph Orsenigo, Darryl Palmer, Jane Polston, Greg Powell, Gordon Prine, Ken Quesenberry, Jay Scott, Brian Scully, Wayne Sherman, Tom Stadsklev, Berry Treat, Tim White, David Wofford, Ashley Wood, Thomas Wright, and Tracy D. Zwillinger 